\title{
Late Archean basement in the Bangenhuken Complex of the Nordbreen Nappe, western Ny-Friesland, Svalbard
}

\author{
Fredrik J. Hellman, David G. Gee \\ \& Patrik Witt-Nilsson
}

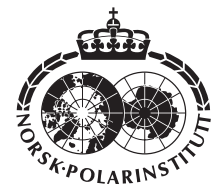

\begin{abstract}
The rocks of western Ny-Friesland, northern Svalbard, are part of a tectonostratigraphy including four thrust sheets, each composed mainly of orthogneisses overlain by younger metasedimentary rocks. Previous geochronological studies have shown that the orthogneisses are dominated by ca. 1750 Mya granitoids. This study of a quartz-monzonite in one of the thrust sheets, the Nordbreen Nappe, yields a single-zircon U-Pb ion-microprobe age of $2709 \pm 28 \mathrm{My}$. This is the oldest rock unit so far reported in the Svalbard Caledonides. However, age-determinations on detrital zircons in the metasediments of western Ny-Friesland have shown that Late Archean rocks were prominent sources. The new ages presented here provide the first evidence of a local source for these sedimentary rocks.
\end{abstract}

F. J. Hellman, Dept. of Mineralogy and Petrology, Lund University, Sölvegatan 13, SE-223 62 Lund, Sweden (currently at Scancem Research AB, Box 104, SE-62030 Slite, Sweden); D. G. Gee \& P. Witt-Nilsson, Dept. of Geophysics, Uppsala University, Villavägen 16, SE-752 36 Uppsala, Sweden.

The Old Red Sandstones (O.R.S.) and younger rocks in Svalbard overlie a pre-Devonian basement which comprises tectonostratigraphically different terranes (Fig. 1a; Harland \& Gayer 1972; Harland 1985, 1997) that were brought together along major north-south trending, sinistral transcurrent faults during the Caledonian Orogeny (Harland 1985; Gee \& Page 1994).

This study focuses on rocks exposed in western Ny-Friesland (Fig. 1b). In this area (Harland 1959; Harland, Scott et al. 1992; Harland, Wallis et al. 1996), the structurally lowest units outcrop in a major north - south trending fold called the Atomfjella Antiform (Fig. 1b). A ca. $8 \mathrm{~km}$ thick succession of orthogneisses and metasediments has been described to be dominantly of volcanosedimentary origin (Harland, Scott et al. 1992; Harland, Wallis et al. 1966; Harland 1997). This succession has been interpreted to be interrupted by several thrusts and occurs in an antiformal thrust stack (Gee et al. 1994; Witt-Nilsson et al. 1998). Each thrust sheet is composed of crys- talline "basement" overlain by metasedimentary cover. Late Palaeoproterozoic granitic gneisses dominate the "basement" (Johansson et al. 1995); older rocks have not previously been identified. However, both older Palaeoproterozoic and Late Archean outcrops have provided detritus to the associated metasediments (Gee \& Hellman 1996; Hellman et al. 1997; Hellman \& Witt-Nilsson 1999). In addition, further east on Nordaustlandet, a granitic boulder of Late Archean age has been identified in Vendian tillites in the Wahlenbergfjorden area (Larionov, Johansson \& Gee 1998). Reported here is the first U-Pb zircon evidence from the Atomfjella Antiform of Late Archean magmatic rocks in western Ny-Friesland.

Geological setting and previous geochronology of western Ny-Friesland

The metamorphosed succession of western NyFriesland - the Atomfjella Complex of Kra- 


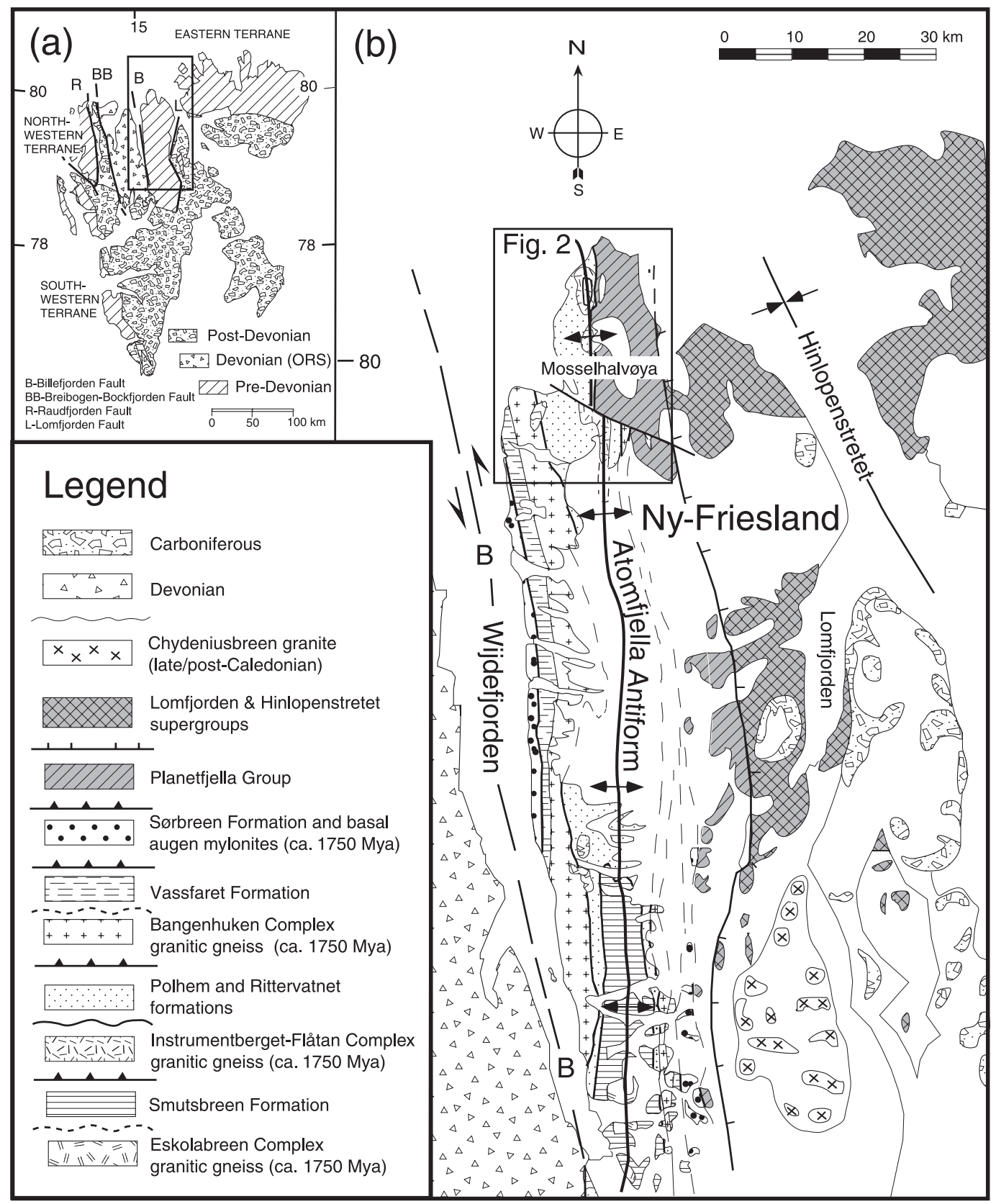

Fig. 1. (a) Svalbard's Caledonian terranes, modified from Gee 1986. (b) Geological map of Ny-Friesland, modified from Gee et al. (1994).

sil'shchikov (1965)—contains metasediments separated by granitic gneisses. Those authors favouring the western Ny-Friesland succession to be more or less continuous and unbroken (Harland
1997; Krasil'shchikov 1965) interpret the granitic gneisses to be metamorphosed ignimbrites (e.g. Harland 1997: 237-238). Most contacts between the sedimentary and igneous rocks are highly 
strained. Quantifying the strain in the field in terms of displacement between rock units has not been possible. Decisive evidence for thrust repetition of the succession has been found in the isotope ages and provenance data summarized below.

The Caledonian tectonostratigraphy of western Ny-Friesland, includes four thrust sheets (Fig. 2) from base upwards; the Finnlandsveggen, Rekvika, Nordbreen and Dirksodden nappes (WittNilsson et al. 1998). They are all metamorphosed in amphibolite facies. Each of the four thrust sheets contains granitic gneisses of ca. $1750 \mathrm{My}$ age (Johansson et al. 1995; Larionov, Johansson, Tebenkov et al. 1995; Johansson \& Gee 1999) and overlying cover sediments (Gee \& Hellman 1996; Hellman et al. 1997) containing zircons that are both older and younger (Mesoproterozoic) than the "basement".

The lowest thrust sheet, the Finnlandsveggen Nappe (Fig. 2), includes highly deformed gneisses and amphibolites of the Eskolabreen Complex. Granitic gneisses in this unit have been dated to $1749 \pm 18,1748 \pm 21$ and $1734 \pm 5$ Mya (Johansson $\&$ Gee 1999). One multigrain U-Pb zircon age of $2415 \pm 34$ My (Balashov et al. 1993) on a grey paragneiss has recently been shown to be of no geological significance due to mixing of older and younger zircons (Larionov, unpubl. data). Two samples of psammites from the Smutsbreen Formation, overlying the Eskolabreen Complex, have yielded nearly thirty detrital zircon $\mathrm{Pb}$-evaporation ages dominated by three groups, $1190-1300 \mathrm{My}$, 1560 - 1710 My and 2560 - 2680 My, with a dominance in the Mesoproterozoic (Gee \& Hellman 1996).

In the overlying Rekvika Nappe (Fig. 2), a basal granitic unit, the Instrumentberget gneiss, is overlain by conglomerates and quartzites of the Polhem Formation and metapelites with intercalated calcareous and quartzitic horizons of the Rittervatnet Formation. U-Pb zircon data on the Instrumentberget granitic gneiss yielded an age of $1735 \pm 13$ My and two granitic boulders in the overlying conglomerates yielded similar ages of $1739 \pm 2 \mathrm{My}$ and $1738 \pm 5$ My (Hellman et al. 1997), suggesting that some of the boulders were derived from the underlying "basement". Additional, single-zircon, $\mathrm{Pb}$-evaporation analyses from a quartzite higher up in the stratigraphy of the Polhem Formation yielded detrital zircons dominated by 1740 to 2040 My ages. Another quartzite within the same formation, collected in southern Ny-Friesland, has provided provenance ages of ca. 1320, 1510, 1870, 1970 and $2710 \mathrm{My}$ (Hellman et al. 1997).

Granitic gneisses in the basal unit of the overlying Nordbreen Nappe (Fig. 2) also yield ca. 1750 My ages (data from six localities; Johansson et al. 1995). The granites contain both metaigneous and metasedimentary xenoliths, including large intercalations of the latter; together they compose the Bangenhuken Complex. The granites intrude overlying Vassfaret Formation sedi-

Table 1. Major and trace element data from the quartz-monzonite.

\begin{tabular}{lrrrcrrr}
\hline $\begin{array}{l}\text { Major element } \\
\text { (wt\%) }\end{array}$ & 1 & 2 & 3 & $\begin{array}{c}\text { Trace element } \\
(\mathrm{ppm})\end{array}$ & 1 & 2 & 3 \\
\hline $\mathrm{SiO}_{2}$ & 61.77 & 61.01 & 60.64 & $\mathrm{U}$ & 3 & 1 & 3 \\
$\mathrm{Al}_{2} \mathrm{O}_{3}$ & 15.80 & 15.85 & 15.66 & $\mathrm{Th}$ & 14 & 14 & 13 \\
$\mathrm{Fe}_{2} \mathrm{O}_{3}$ & 5.90 & 6.07 & 6.36 & $\mathrm{Zn}$ & 68 & 70 & 74 \\
$\mathrm{MnO}_{\mathrm{MgO}}$ & 0.09 & 0.09 & 0.09 & $\mathrm{Cu}$ & 30 & 32 & 30 \\
$\mathrm{CaO}$ & 2.43 & 2.53 & 2.67 & $\mathrm{Ni}$ & 19 & 18 & 20 \\
$\mathrm{Na}$ & 4.02 & 4.35 & 4.48 & $\mathrm{Ba}$ & 1478 & 1451 & 1450 \\
$\mathrm{~K}_{2} \mathrm{O}$ & 3.54 & 4.02 & 3.71 & $\mathrm{Sc}$ & 12 & 14 & 14 \\
$\mathrm{TiO}$ & 5.22 & 5.04 & 4.95 & $\mathrm{~S}$ & 188 & 238 & 194 \\
$\mathrm{P}_{2} \mathrm{O}_{5}$ & 0.61 & 0.64 & 0.64 & $\mathrm{Cr}$ & 184 & 132 & 174 \\
$\mathrm{Total}$ & 0.39 & 0.43 & 0.41 & $\mathrm{~V}$ & 98 & 97 & 108 \\
$\mathrm{Trace}$ element & 99.75 & 100.02 & 99.61 & $\mathrm{La}$ & 72 & 60 & 102 \\
$(\mathrm{ppm})$ & & & & $\mathrm{Pb}$ & 45 & 35 & 36 \\
$\mathrm{Nb}$ & & & & & & & \\
$\mathrm{Y}$ & 9 & 10 & 9 & $\mathrm{Ga}$ & 18 & 20 & 27 \\
$\mathrm{Rb}$ & 25 & 27.6 & 26.8 & $\mathrm{Co}$ & 14 & 16 & 20 \\
$\mathrm{Zr}$ & 210 & 203 & 198 & $\mathrm{Ce}$ & 149 & 143 & 160 \\
$\mathrm{Sr}$ & 217 & 195 & 231 & $\mathrm{Nd}$ & 65 & 58 & 68 \\
\hline & 650 & 650 & 636 & $\mathrm{As}$ & 8 & 7 & 8 \\
\hline
\end{tabular}




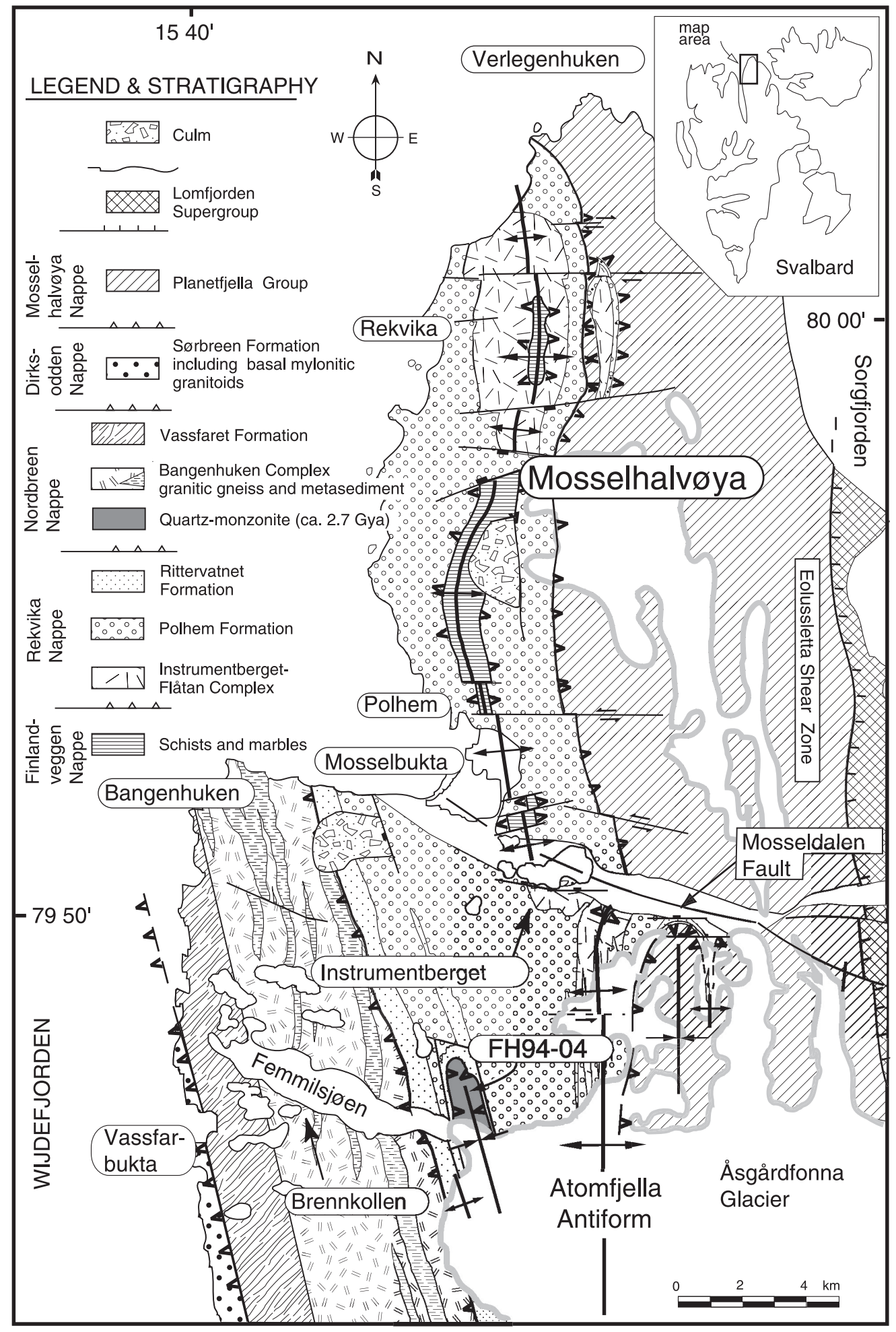

Fig. 2. Northern Ny-Friesland, modified from Witt-Nilsson et al (1998). 

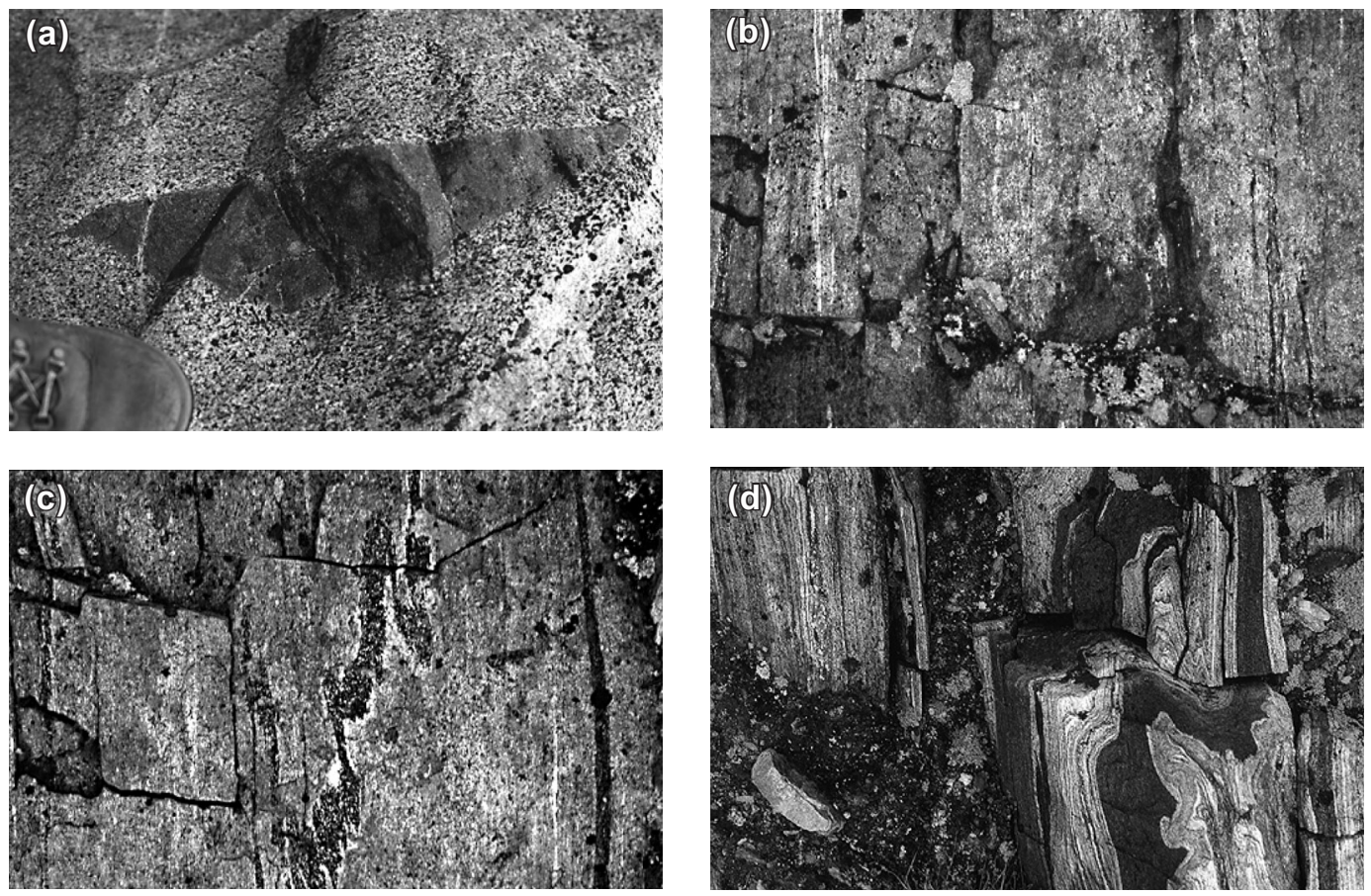

Fig. 3. (a) Little deformed quartz-monzonite with mafic xenolith. (b) Banded quartz-monzonite mylonite at the base of Nordbreen Nappe. (c) Mylonitic metasediment at the top of Rittervatnet Formation. (d) Folded quartzite and amphibolite in the underlying Rittervatnet Formation.

ments. However, the Vassfaret Formation, from its middle to upper parts, has yielded ca. 1750 Mya detrital zircons. It has therefore been concluded (Hellman \& Witt-Nilsson 1999) that the basal part of the formation, as described by Gayer \& Wallis (1966), is part of an older pre-1750 Mya sedimentary succession (similar to that found in the xenoliths) and the middle to upper part is a younger sedimentary cover. Three samples collected in the middle to upper levels of the Vassfaret Formation yield 34 detrital zircon ages of 1735, 1920 - 2045 and 2540 - 2725 My (Hellman \& Witt-Nilsson 1999).

At the base of the uppermost thrust sheet, the Dirksodden Nappe (Fig. 2), in the Sørbreen Formation, several horizons of a conspicuous finegrained feldspar-megacrystic quartzofeldspathic rock have been observed. This rock has been interpreted to be either of volcanic (Gayer \& Wallis 1966) or of mylonitic origin (Manby 1990; Witt-Nilsson 1999) and is dated to $1747 \pm 11$ My (Johansson, unpubl. U-Pb zircon age). The quartzites of the Sørbreen Formation have been sampled at three stratigraphic levels and the detrital zir- cons vary in age from 1720 to 2800 My (Hellman \& Witt-Nilsson 1999).

\section{Sample locality and geochemistry}

During the 1994 field season, a previously unknown unit of magmatic rock was discovered in Ny-Friesland. It is located in a klippe ca. $500 \mathrm{~m}$ north-east of Femmilsjøen (Fig. 2), apparently at the same structural level as the base of the Bangenhuken Complex in the Nordbreen Nappe. The contact relationships between the "normal" ca. 1750 Mya granitic-gneisses of the Bangenhuken Complex and the new rock type are not exposed. However, it is clear that the rocks are exposed in a synform (Fig. 2) and the lower contact to the Rittervatnet Formation (Fig. 2) is deformed to a banded mylonite (Fig. 3b). The latter becomes more quartz-rich downwards and goes over to fine-banded ( $0.5-5 \mathrm{~cm}$ thick) feldspar-quartz, psammites and amphibolites of the Rittervatnet Formation (Fig. 3c). Below the contact these sediments are better preserved but extensively folded 

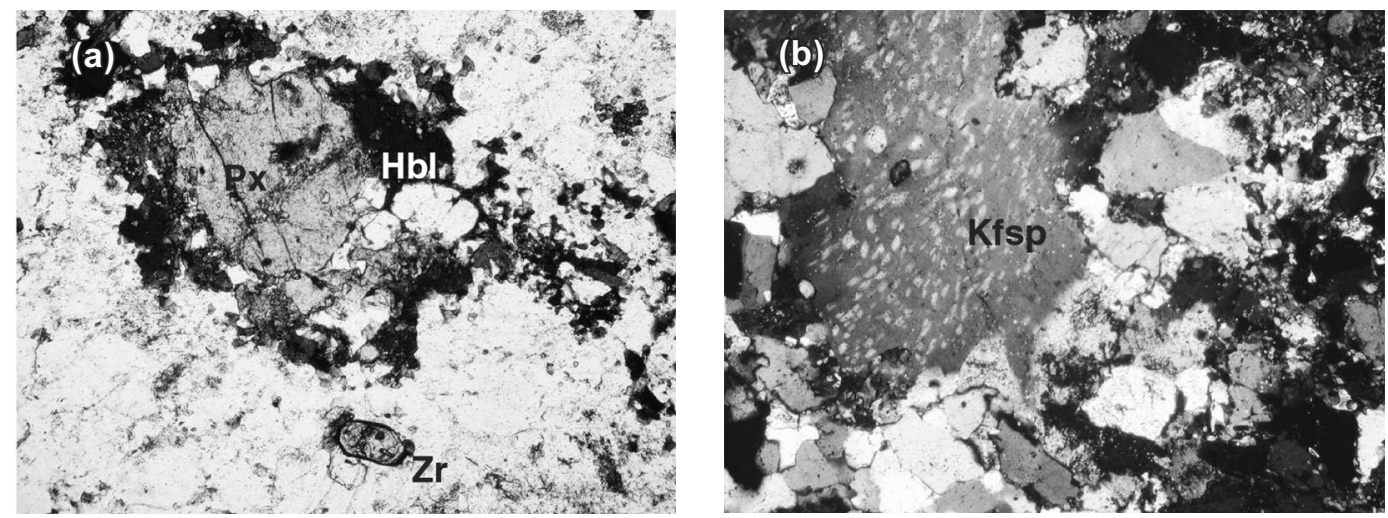

Fig. 4. Thin-section of the quartz-monzonite. (a) Showing a reaction rim of hornblende (Hbl) around pyroxene (Px); also a zircon $(\mathrm{Zr})$, and (b) showing a phenocryst of perthitic K-feldspar (Kfsp) in a K-feldspar dominated matrix with some plagioclase and quartz.

(Fig. 3d) and boudinaged.

This newly discovered magmatic rock is medium to coarse-grained and partly almost undeformed (Fig. 3a) and greyish, locally with dark xenoliths (Fig. 3a), probably of magmatic origin. The rock is composed of K-feldspar, plagioclase, quartz, clinopyroxene, hornblende and biotite, with accessory ilmenite, zircon, apatite and titanite. The dominating grey K-feldspar often has perthitic intergrowths of plagioclase (Fig. 4b). The plagioclase is subordinate and has an $\mathrm{An}_{70}$ composition. The pyroxenes have small intergrowths of ilmenite and often exhibit a reaction rim of green hornblende (Fig. 4a), probably developed during the Caledonian metamorphic overprinting. In the more deformed parts, some ilmenite crystals have a thin rim of titanite.

Three samples were chosen for geochemical analysis at the School of Geological and Computer Sciences, University of Natal, Durban, South Africa. Major and minor elements were analysed using the lithium tetraborate fusion method of
Norrish \& Chappel (1977) with the trace elements analysed using pressed powder pellets. The samples were analysed by X-ray fluorescence spectrometry using a Philips PW1404 and X-unique spectrometer. Instrument calibration was controlled using international standards, internal synthetic standards and blanks.

The results are reported in Table 1. Total alkali contents $\left(\mathrm{K}_{2} \mathrm{O}+\mathrm{Na}_{2} \mathrm{O}\right)$ are plotted versus silica $\left(\mathrm{SiO}_{2}\right)$ in discrimination diagrams by Cox et al. (1979), used for plutonic rocks by Wilson (1989). The data fall in the syeno-diorite field (Fig. 5a). In a P-Q diagram (Fig. 5b; Debon \& Le Fort 1983) the data fall in the quartz-monzonite field which is approximately equivalent to syeno-diorite using the nomenclature by Streckeisen (1976). We have chosen here to refer to the rock as quartz-monzonite.

The best preserved part of the quartz-monzonite was sampled for both the chemical analyses and an $\mathrm{U} / \mathrm{Pb}$ zircon study; xenoliths were avoided.

Table 2. Conventional U-Pb zircon data from the quartz-monzonite. (Table continued next page.)

\begin{tabular}{|c|c|c|c|c|c|c|c|c|c|c|}
\hline $\begin{array}{l}\text { Analyse } \\
\text { fraction }\end{array}$ & $\begin{array}{c}\text { No. of } \\
\text { crystals }\end{array}$ & $\begin{array}{c}\text { Size } \\
(10-6 \mathrm{~m})\end{array}$ & $\begin{array}{l}\text { Weight } \\
(\mathrm{mg})\end{array}$ & $\begin{array}{c}\mathrm{U} \\
(\mathrm{ppm})\end{array}$ & $\begin{array}{c}\text { Pb-rad } \\
(\mathrm{ppm})\end{array}$ & $\begin{array}{c}\mathrm{Pb}-\mathrm{Com} \\
(\mathrm{ppm})\end{array}$ & $\begin{array}{c}{ }^{206} \mathrm{~Pb} /{ }^{204} \mathrm{~Pb} \\
\text { ratio }^{\mathrm{a}}\end{array}$ & $\begin{array}{c}{ }^{206} \mathrm{~Pb} /{ }^{208} \mathrm{~Pb} \\
\text { ratio }^{\mathrm{b}}\end{array}$ & $\begin{array}{c}{ }^{207} \mathrm{~Pb} /{ }^{235} \mathrm{U} \\
\text { ratio }^{\mathrm{b}}\end{array}$ & $\begin{array}{l} \pm 2 \sigma \\
(\%) \\
\end{array}$ \\
\hline 1 & 12 & $100-120$ & 0.034 & 545 & 304 & 0.98 & 15300 & 7.170 & 12.37 & 0.326 \\
\hline 2 & 19 & $70-80$ & 0.016 & 492 & 266 & 0.89 & 14400 & 7.672 & 12.08 & 0.444 \\
\hline 3 & 22 & $100-150$ & 0.066 & 565 & 310 & 0.33 & 44700 & 7.036 & 12.23 & 0.364 \\
\hline 4 & 47 & $60-80$ & 0.064 & 500 & 269 & 3.2 & 4000 & 7.179 & 12.05 & 0.200 \\
\hline 5 & 2 & 150 & 0.0052 & 1448 & 795 & 8.4 & 5400 & 7.836 & 12.51 & 0.122 \\
\hline 6 & 6 & 100 & 0.0084 & 693 & 370 & 7.6 & 2800 & 6.831 & 11.90 & 0.196 \\
\hline
\end{tabular}



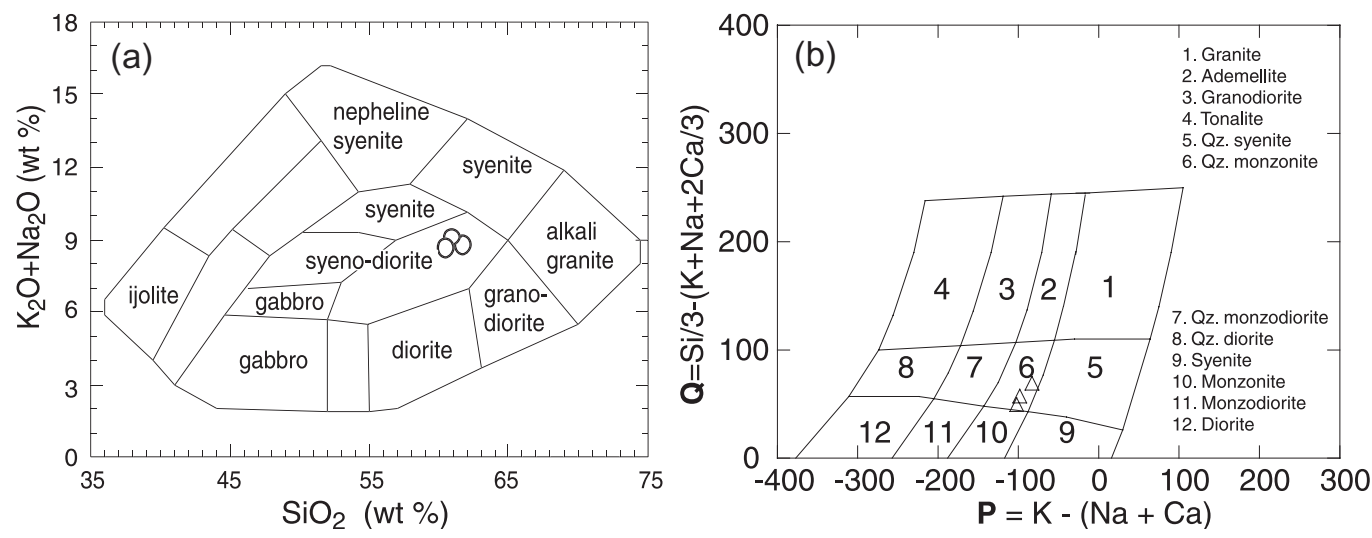

Fig. 5. The data plotted in discrimination diagrams to make a rock classification: (a) diagram for plutonic rocks modified from Fig. 1.2b in Wilson (1989, Igneous petrogenesis: a global tectonic approach, p. 8; used with kind permission of Kluwer Academic Publishers and the author); (b) diagram adapted from Fig. 1 in Debon \& Le Fort (1983, Transactions of the Royal Society of Edinburgh: Earth Sciences 73 [1983, for 1982], p. 136; modified with kind permission of the Royal Society of Edinburgh and the authors).

\section{Zircon geochronology and results}

The zircons were separated at the Department of Geology, Lund University, using standard procedures, involving crushing, Wilfley table and Franz magnetic separator. Zircons were selected for analysis by handpicking in alcohol under a microscope. The chemical preparation and mass spectrometer (TIMS) analyses were made at the Laboratory for Isotope Geology at the Swedish Museum of Natural History. Ion-microprobe analyses were made at the NORDSIM laboratory at the Swedish Museum of Natural History.

\section{Conventional $\mathrm{U}-\mathrm{Pb}$ method}

The zircons are translucent, colourless to light yellow and short-prismatic, mostly with rounded surfaces; a few are long-prismatic and have a length to width ratio of more than $4: 1$. The most

\begin{tabular}{|c|c|c|c|c|c|}
\hline $\begin{array}{l}{ }^{206} \mathrm{~Pb} /{ }^{238} \mathrm{U} \\
\text { ratio }^{\mathrm{b}}\end{array}$ & $\begin{array}{l} \pm 2 \sigma \\
(\%)\end{array}$ & $\begin{array}{c}{ }^{207} \mathrm{~Pb} /{ }^{206} \mathrm{~Pb} \\
\text { ratio }\end{array}$ & $\begin{array}{l} \pm 2 \sigma \\
(\%)\end{array}$ & $\begin{array}{c}{ }^{207} \mathrm{~Pb} /{ }^{206} \mathrm{~Pb} \\
\text { age (My) }\end{array}$ & $\begin{array}{l}\text { Error }^{\circ} \\
\text { corr. }\end{array}$ \\
\hline 0.4843 & 0.315 & 0.1852 & 0.083 & $2700 \pm 1$ & 0.967 \\
\hline 0.4770 & 0.433 & 0.1836 & 0.091 & $2691 \pm 1$ & 0.979 \\
\hline 0.4813 & 0.358 & 0.1843 & 0.067 & $2692 \pm 1$ & 0.983 \\
\hline 0.4758 & 0.185 & 0.1837 & 0.074 & $2687 \pm 1$ & 0.929 \\
\hline 0.4881 & 0.114 & 0.1859 & 0.044 & $2706 \pm 1$ & 0.933 \\
\hline 0.4710 & 0.187 & 0.1832 & 0.056 & $2682 \pm 1$ & 0.959 \\
\hline
\end{tabular}

${ }^{\mathrm{c}}$ Error correlation. clear and pristine zircons were separated into six different size fractions by handpicking. One fraction (3) consists of long-prismatic zircons. Fraction 1, 2, 4, 5 and 6 were air-abraded using the method described by Krogh (1982).

The chemical preparation follows Krogh (1973) with dissolution of the zircons in $\mathrm{HF}+\mathrm{HNO}_{3}(10: 1)$ in microcapsules (Parrish 1987) placed in stainless steel bombs at $205{ }^{\circ} \mathrm{C}$. Fractions 1 to 4 were spiked with a ${ }^{208} \mathrm{~Pb} /{ }^{233} \mathrm{U} / 235 \mathrm{U}$ tracer, whereas fraction 5 and 6 where spiked with a ${ }^{205} \mathrm{~Pb} /{ }^{233} \mathrm{U} /$ ${ }^{235} \mathrm{U}$ tracer. $\mathrm{U}$ and $\mathrm{Pb}$ were extracted using ion exchange in $\mathrm{HCl}$ and analysed on a Finnigan MAT 261 mass spectrometer. The common lead correction follows Stacey \& Kramers (1975). The $\mathrm{Pb}$ analyses are corrected for fractionation by $0.10 \pm 0.04 \% /$ mass unit and $\mathrm{U}$ according to measured ${ }^{233} \mathrm{U} /{ }^{235} \mathrm{U}$ ratios.

The age and error calculations are made using PBDAT (Ludwig 1991) and Isoplot (Ludwig 1998). The six analysed fractions (Table 2) are ca. 6 - $10 \%$ discordant and a combined regression line through the six analyses yields an upper intercept age of $2764 \pm 33$ My and a lower intercept of $1207 \pm 290$ ( 2 sigma) My with a MSWD of 5.2 in Fig. 6 a.

\section{U-Pb ion-microprobe method}

Handpicked zircons were cast in epoxy and then polished until a cross-section was obtained 
through the central part of the crystals. Electron backscatter images show that most of the zircons have a diffuse oscillatory zoning; some also have rounded core-like domains (Fig. 7).

The analyses were made on a Cameca IMS 1270 ion-microprobe with high sensitivity and high mass-resolution. The analytical procedure follows Whitehouse, Cleasson et al. (1997) and Whitehouse, Kamber et al. (1999). Data were calibrated using Geostandards 91500 (Wiedenbeck et al. 1995) and if necessary corrected for initial lead using the Stacey \& Kramers (1975) model. An external error, based upon the standard measurements during a specific analytical session, was propagated onto the observed errors from the unknowns. Errors in ${ }^{207} \mathrm{~Pb} /{ }^{206} \mathrm{~Pb}$ ratios are observed errors, which generally exceed counting statistical errors. The errors are given at the 1 sigma confidence level (Table 3 ) and the calculated intercept ages are at the 2 sigma level (Fig. $6 b)$.

Electron backscatter images (Fig. 7) were used to select domains to be analysed by the ca. $30 \mu \mathrm{m}$ diameter spot of the ion-microprobe. Different domains of the zircons were analysed (Fig. 7) and

Fig. 6. Concordia diagrams showing (a) conventional and (b) ion-microprobe results.
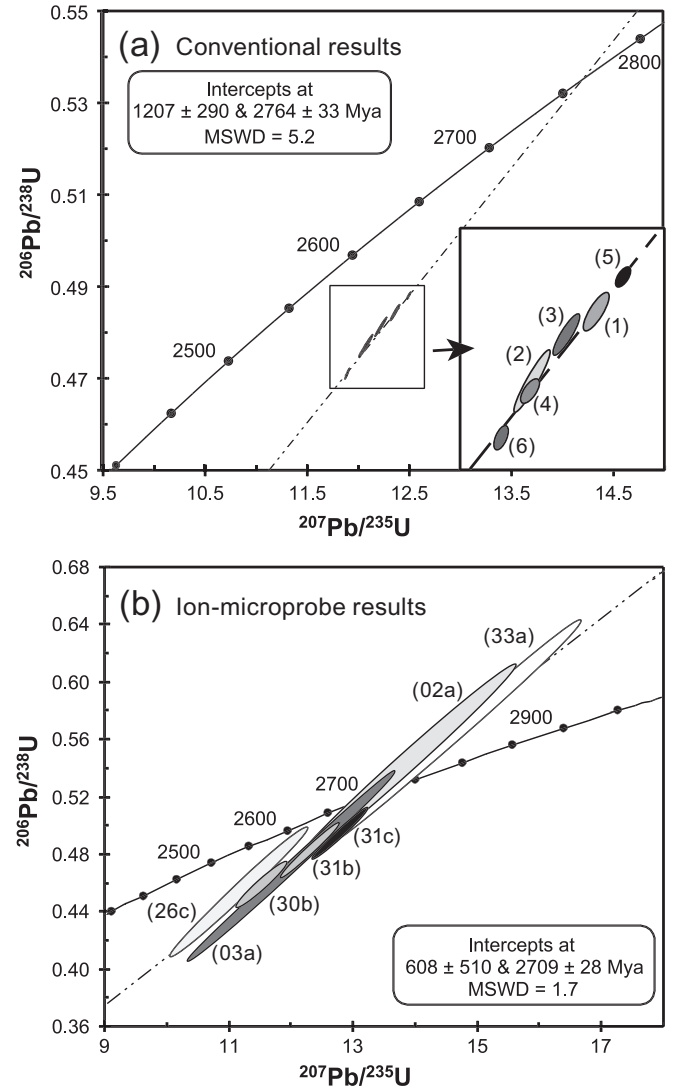

Table 3. Ion-micriprobe zircon data from the quartz-monzonite. Errors on ages and ratios are at the 1 sigma confidence level and corrected for common lead (Stacey \& Kramers 1975) if necessary. The data is calibrated using Geostandard 91500 (Wiedenbeck et al. 1995). Analyses written in italics have not been calibrated for Geostandard 91500 (see text). (Table continued next page.)

\begin{tabular}{|c|c|c|c|c|c|c|c|c|c|c|}
\hline $\begin{array}{l}\text { Grain }^{\mathrm{a}} \\
\text { (spot) }\end{array}$ & $\begin{array}{c}\mathrm{U} \\
(\mathrm{ppm})\end{array}$ & $\begin{array}{c}\mathrm{Pb} \\
(\mathrm{ppm})\end{array}$ & $\begin{array}{c}\mathrm{Th} \\
(\mathrm{ppm})\end{array}$ & $\begin{array}{c}\mathrm{Th} / \mathrm{U} \\
\text { (means) }\end{array}$ & $\begin{array}{l}\mathrm{f}_{206} \\
(\%)\end{array}$ & ${ }^{207} \mathrm{~Pb} /{ }^{206} \mathrm{~Pb}$ & $\begin{array}{l} \pm \sigma \\
(\%)\end{array}$ & ${ }^{207} \mathrm{~Pb} /{ }^{235} \mathrm{U}$ & $\begin{array}{l} \pm \sigma \\
(\%)\end{array}$ & ${ }^{206} \mathrm{~Pb} /{ }^{238} \mathrm{U}$ \\
\hline $02 a^{*}$ & 506 & 381 & 493 & 0.975 & 0.00 & 0.18530 & 0.72 & 13.885 & 5.21 & 0.54345 \\
\hline $02 b$ & 431 & 295 & 416 & 0.965 & 0.00 & 0.19190 & 1.26 & 12.867 & 7.17 & 0.48613 \\
\hline 03a* & 2272 & 1289 & 220 & 0.097 & 0.00 & 0.18480 & 0.45 & 11.996 & 5.83 & 0.47079 \\
\hline $25 a$ & 489 & 297 & 337 & 0.689 & 0.01 & 0.18680 & 0.25 & 11.155 & 2.89 & 0.43311 \\
\hline $25 b$ & 789 & 447 & 360 & 0.457 & 0.02 & 0.18339 & 0.66 & 10.918 & 1.91 & 0.43181 \\
\hline $26 a$ & 280 & 182 & 244 & 0.868 & 0.01 & 0.18830 & 0.30 & 11.550 & 2.89 & 0.44486 \\
\hline $26 b$ & 556 & 302 & 217 & 0.390 & 0.13 & 0.17560 & 0.33 & 10.138 & 2.87 & 0.41872 \\
\hline $26 c^{*}$ & 802 & 462 & 308 & 0.384 & 0.22 & 0.17787 & 0.66 & 11.115 & 4.02 & 0.45321 \\
\hline $27 \mathrm{a}$ & 325 & 176 & 209 & 0.644 & 0.02 & 0.17930 & 0.41 & 9.8336 & 1.50 & 0.39777 \\
\hline $28 \mathrm{a}$ & 518 & 307 & 285 & 0.549 & 0.01 & 0.18520 & 0.29 & 11.244 & 2.87 & 0.44032 \\
\hline $29 a$ & 246 & 150 & 185 & 0.752 & 0.01 & 0.18560 & 0.53 & 10.975 & 2.90 & 0.42887 \\
\hline $29 b$ & 285 & 189 & 156 & 0.548 & 0.01 & 0.18840 & 0.48 & 12.772 & 2.98 & 0.49167 \\
\hline $30 \mathrm{a}$ & 431 & 260 & 286 & 0.663 & 0.03 & 0.19058 & 0.60 & 11.561 & 1.56 & 0.43996 \\
\hline $30 b^{*}$ & 284 & 177 & 173 & 0.610 & 0.02 & 0.18210 & 0.44 & 11.537 & 1.53 & 0.45949 \\
\hline $31 a$ & 252 & 145 & 184 & 0.730 & 0.00 & 0.17640 & 0.34 & 9.9969 & 2.87 & 0.41102 \\
\hline $31 b^{*}$ & 282 & 192 & 223 & 0.791 & 0.01 & 0.18490 & 0.30 & 12.308 & 1.56 & 0.48279 \\
\hline $31 c^{*}$ & 265 & 177 & 159 & 0.599 & 0.02 & 0.18760 & 0.32 & 12.800 & 1.48 & 0.49484 \\
\hline $33 \mathrm{a}^{*}$ & 340 & 262 & 295 & 0.866 & 0.06 & 0.18817 & 0.58 & 14.630 & 5.75 & 0.56387 \\
\hline $33 b$ & 217 & 164 & 202 & 0.931 & 0.06 & 0.18056 & 0.79 & 13.811 & 6.41 & 0.55478 \\
\hline
\end{tabular}

${ }^{a}$ Asterisks denote that the analyse point is used in the combined age calculation (Fig 5b) and fulfil the criteria of being less than $\pm 10 \%$ discordant and have $\mathrm{U} / \mathrm{Pb}$ ages with less than $6 \%$ error. 


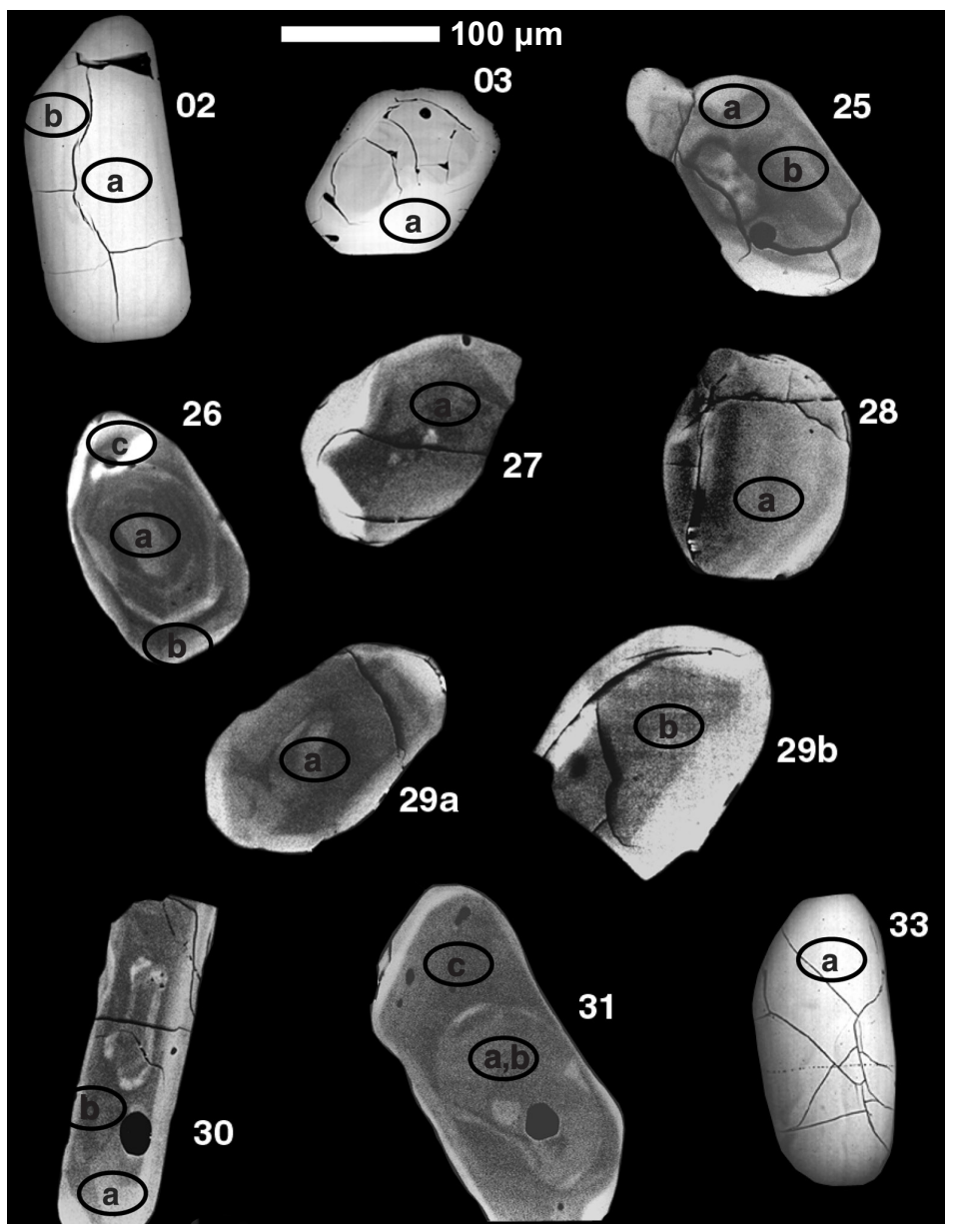

Fig. 7. Electron backscatter images of the analysed zircons (numbers refer to Table 3).

\begin{tabular}{lccc}
\hline $\begin{array}{c} \pm \sigma \\
(\%)\end{array}$ & $\begin{array}{c}{ }^{207} \mathrm{~Pb} / 206 \mathrm{~Pb} \\
\text { age }(\mathrm{My})\end{array}$ & $\begin{array}{c}206 \mathrm{~Pb} /{ }^{238} \mathrm{U} \\
\text { age }(\mathrm{My})\end{array}$ & $\begin{array}{c}\text { Disc. }^{b} \\
(\%)\end{array}$ \\
\hline 5.16 & $2701 \pm 12$ & $2798 \pm 117$ & 0 \\
7.06 & $2759 \pm 21$ & $2555 \pm 149$ & 0 \\
5.81 & $2696 \pm 8$ & $2487 \pm 120$ & 0 \\
2.88 & $2714 \pm 4$ & $2320 \pm 56$ & -12.4 \\
1.80 & $2684 \pm 11$ & $2314 \pm 35$ & -12.4 \\
2.88 & $2727 \pm 5$ & $2372 \pm 57$ & -10.5 \\
2.85 & $2612 \pm 6$ & $2255 \pm 55$ & -11.2 \\
3.96 & $2633 \pm 11$ & $2409 \pm 80$ & -2.6 \\
1.44 & $2646 \pm 7$ & $2159 \pm 26$ & -18.9 \\
2.85 & $2700 \pm 5$ & $2352 \pm 56$ & -10.4 \\
2.85 & $2704 \pm 9$ & $2301 \pm 55$ & -12.6 \\
2.94 & $2728 \pm 8$ & $2578 \pm 63$ & -0.9 \\
1.44 & $2747 \pm 10$ & $2350 \pm 28$ & -13.9 \\
1.46 & $2672 \pm 7$ & $2437 \pm 30$ & -7.4 \\
2.85 & $2619 \pm 6$ & $2220 \pm 54$ & -13.1 \\
1.53 & $2697 \pm 5$ & $2539 \pm 32$ & -4.0 \\
1.45 & $2721 \pm 5$ & $2592 \pm 31$ & -2.8 \\
5.72 & $2726 \pm 10$ & $2883 \pm 133$ & 0 \\
6.37 & $2658 \pm 13$ & $2845 \pm 146$ & 0
\end{tabular}

the results of all nineteen spots are given in Table 3. A discordant standard zircon (91500) was used during one of the analytical sessions, and it was therefore not possible to calibrate some of the data. These data are written in italics (Table 3) and not used in the age calculations. However, the observed ${ }^{207} \mathrm{~Pb} / 206 \mathrm{~Pb}$ ages are not significantly different from the calibrated ratios. If all calibrated data (Table 3) are used, an upper intercept age is calculated to be $2705 \pm 31$ My with a MSWD of 8.0. In this paper we prefer to put more confidence in the data that are less than $10 \%$ discordant at the 2 sigma level and have $\mathrm{U} / \mathrm{Pb}$ ratios with less than $6 \%$ errors (Table 3 ). These data are marked with asterisks in Table 3 and yield an upper intercept of $2709 \pm 28$ My with a MSWD of 1.7 (Fig. 6b).

${ }^{\mathrm{b}}$ Discordancy within 2 sigma level. 


\section{Interpretation of isotope data}

The conventional (TIMS) method yields high analytical precision for each data point. However, if the obtained results are discordant, it is hard to make a confident interpretation of the data because they may represent multiple zircon growth phases in single crystals or even different zircon age populations. On the other hand, ion-microprobe data have generally poorer analytical precision, but the results represent a small domain (ca. $30 \mu \mathrm{m}$ ) of the zircons. This makes it possible not only to date different zircon populations in one sample, but also to date different domains of one zircon separately. The chances of mixing different age domains and zircon populations are less likely with an ion-microprobe; therefore, each analysis has greater geological significance. In the analysed rock some of the zircons are prismatic, with typical magmatic morphology; many have rounded surfaces. The consistent age data from cores and rims suggest that the zircons were formed during a single magmatic event, but many of the crystals have probably been subject to different degrees of resorption perhaps due to the Caledonian amphibolite facies metamorphism.

The two methods yield the results of $2764 \pm 33$ Mya (Fig. 6a) for the conventional (TIMS) and $2709 \pm 28$ Mya (Fig. 6b) for the ionmicroprobe. A high MSWD of 5.2 of the regression lines indicates a large scatter around the best-fit line for the conventional (TIMS) method. Mixing of two zircon populations in combination with Pb-loss could explain the observed data scatter, but the ion-microprobe data were not able to identify different zircon populations. The most likely explanation for the scatter of the conventional (TIMS) data and the discordancy of the zircons is a complex history of $\mathrm{Pb}$-loss (more than two stages). In western Ny-Friesland two tectonothermal events are known: one associated with the intrusion of the ca. 1750 Mya granitoids and a second in Caledonian time associated with transpression under high amphibolite facies conditions. It is possible that both these events and probably also a recent $\mathrm{Pb}$-loss have effected the zircons. The ion-microprobe data are less discordant and scatter less (MSWD of 1.7; Fig. 6a, b). Therefore, we regard the ion-microprobe data to be more reliable than the conventional (TIMS) data. Consequently, we consider $2709 \pm 28$ My (Fig. 6b) to be the best estimate of the age of the quartz-monzonite.

\section{Summary and discussion}

The tectonostratigraphy in western Ny-Friesland includes four thrust sheets, each composed of a "basement" complex overlain by younger metasedimentary rocks. The "basement" has previously been shown to be fairly homogenous, dominated by ca. 1750 My old granitic gneisses (Johansson et al. 1995) and some minor sedimentary lenses including xenoliths (Gayer \& Wallis 1966; Witt-Nilsson et al. 1998). This study shows that the basement, at least in the Nordbreen Nappe, also includes Late Archean quartzmonzonites of ca. 2710 My age.

Geochronological studies of detrital zircons in the metasediments from each of the thrust sheets (Hellman et al 1997; Hellman \& Witt-Nilsson 1999) has shown that the provenance for these sediments was dominated by Palaeoproterozoic bedrock of $1700-1750 \mathrm{My}, 1850$ - $2050 \mathrm{My}$ and late Archean 2500 - 2800 My ages. In the Rekvika Nappe, conglomerate boulders in the basal parts of the formation have been dated to 1740 Mya and the same age was obtained from the underlying basement. Apparently, ca. 1750 Mya basement contributed directly to the cover sediments; similarly, it is probable that some of the late Archean detrital zircons found in the metasediments were derived from the Late Archean basement reported here from the Nordbreen Nappe. It seems likely that further analyses of the western Ny-Friesland basement may yield evidence of 1850 - 2050 Mya bedrock, into which the younger Palaeoproterozoic granitoids were intruded.

Acknowledgements.-SWEDARCTIC, NFR and EUROPROBE's Timpebar project have financially supported this work. The staff of the NORDSIM ion-microprobe facility are thanked for all technical assistance, especially Torbjörn Sunde, who sometimes, late in the evenings over the telephone, guided one of us (Hellman) through trouble with the machine. The Laboratory for Isotope Geology (LIG) at the Museum of Natural History is thanked for supporting the conventional U-Pb work. Per-Olof Person is warmly thanked for help with the conventional U-Pb analyses. Åke Johansson, Martin Whitehouse, Tom Andersen, Brian Harland and an anonymous reviewer are thanked for helpful comments on the manuscript. Patrik Witt-Nilsson's research in South Africa was funded by a Swedish Royal Society post-doctoral research grant. Allan Wilson and the staff at the School of Geological Sciences, University of Natal in Durban, are thanked for their help during the geochemical analyses. 


\section{References}

Balashov, Y. A., Larionov, A. N., Gannibal, L. F., Sirotkin, A. N., Tebenkov, A. M., Ryüngenen, G. I. \& Ohta, Y. 1993: An Early Proterozoic U-Pb zircon age from an Eskolabreen Formation gneiss in southern Ny Friesland, Spitsbergen. Polar Res. 12, 174-152.

Cox, K. G., Bell, J. D. \& Pankhurst, R. J. 1979: The interpretation of igneous rocks. London: Allen and Unwin.

Debon, F. \& Le Fort, P. 1983: A chemical-mineralogical classification of plutonic rocks and associations. Trans. R. Soc. Edinb. Earth Sci. 73, 135-149.

Gayer, R. A. \& Wallis, R. H. 1966: The petrology of the Harkerbreen group of the lower Hecla Hoek of Ny Friesland and Olav V Land, Spitsbergen. Nor. Polarinst. Skr. 140. Oslo: Norwegian Polar Institute.

Gee, D. G. 1986: Svalbard's Caledonian terranes reviewed. Geol. Fören. Stockholm Förh. 108, 284-286.

Gee, D. G., Björklund, L. \& Stølen, L.-K. 1994: Early Proterozoic basement in Ny Friesland: implication for the Caledonian tectonics of Svalbard. Tectonophysics 231, 171-182.

Gee, D. G. \& Hellman, F. J. 1996: Zircon Pb-evaporation ages from the Smutsbreen Formation, southern Ny Friesland: new evidence for Caledonian thrusting in Svalbard's Eastern Terrane. Z. Geol. Wiss. 24(3/4), 429-439.

Gee, D. G. \& Page, L. M. 1994: Caledonian terrane assembly on Svalbard: new evidence from ${ }^{40} \mathrm{Ar} /{ }^{39} \mathrm{Ar}$ dating in $\mathrm{Ny}$ Friesland. Amer. J. Sci. 294, 1166-1186.

Harland, W. B. 1959: The Caledonian sequence in Ny Friesland, Spitsbergen. Q. J. Geol. Soc. Lond. 114, 307-343.

Harland, W. B. 1985: Caledonide Svalbard. In D. G. Gee \& B. A. Sturt (eds.): The Caledonide Orogen: Scandinavian and related areas. Pp. 999-1016. Chichester: John Wiley and Sons.

Harland, W. B. 1997: The geology of Svalbard. Geol. Soc. Mem. 17. Oxford: Blackwell.

Harland, W. B. \& Gayer, R. A. 1972: The Arctic Caledonides and earlier oceans. Geol. Mag. 109, 289-384.

Harland, W. B., Scott, R. A., Auckland, R. A. \& Snape, I. 1992: The Ny Friesland Orogen, Spitsbergen. Geol. Mag. 129, 679-708.

Harland, W. B., Wallis, R. H. \& Gayer, R. A. 1966: A revision of the lower Hekla Hoek succession in central north Spitsbergen and correlation elsewhere. Geol. Mag. 103, 70-97.

Hellman, F. J. Gee, D. G. Johansson, Å. \& Witt-Nilsson, P. 1997: Single-zircon Pb-evaporation geochronology constrains basement-cover relationships in the Lower Hecla Hoek of northern Ny Friesland, Svalbard. Chem. Geol. 137, 117-134.

Hellman F. J. \& Witt-Nilsson, P. 1999: Single-zircon geochronology of metasediments and a metadolerite in the tectonostratigraphy of the Ny Friesland orogen, northeastern Spitsbergen (abstract). EUG 10, 28th March-1st April, Strasbourg, France, 1999. J. Conf. Proc. 4(1), 595.

Johansson, Å. \& Gee, D.G. 1999: The late Palaeoproterozoic Eskolabreen granitoids of southern Ny Friesland, Svalbard Caledonides - geochemistry, age and origin. Geol. Fören. Stockholm Förh. 121, 113-126.

Johansson, Å., Gee, D.G., Björklund, L. \& Witt-Nilsson, P. 1995: Isotope studies of granitoids from the Bangenhuken Formation, Ny Friesland Caledonides, Svalbard.
Geol. Mag. 132, 303-320.

Krasil'shchikov, A. A. 1965: Some aspects of the geological history of the northern part of the Spitsbergen Archipelago. In V. N. Sokolov (ed.): Materialii po geologii Shpitsbergena. (Data on the geology of Svalbard.) Pp. 23-25. Leningrad: NIIGA.

Krogh, T. E. 1973: A low-contamination method of U-Pb for hydrothermal decomposition of zircon and extraction of $U$ and $\mathrm{Pb}$ for isotopic age determinations. Geochim. Cosmochim. Acta 37, 485-494.

Krogh, T. E. 1982: Improved accuracy of U-Pb zircon ages by the creation of more concordant systems using an air abrasion technique. Geochim. Cosmochim. Acta 46, 637-649.

Larionov, A. N., Johansson, Å. \& Gee, D. G. 1998: Pb-Pb single-zircon ages of granitoid boulders from vendian tillite of Wahlenbergfjorden, Nordaustlandet, Svalbard. Polar Res. $17,71-80$.

Larionov, A. N., Johansson, Å., Tebenkov, A. M. \& Sirotkin, A. N. 1995: U-Pb Zircon ages from the Eskolabreen Formation, southern Ny Friesland, Svalbard. Nor. Geol. Tidskr. $75,247-257$.

Ludwig, K. R. 1991: A computer program for processing PbU-Th isotope data, version 1.20. U.S. Geol. Surv. Open File Report 88-542.

Ludwig, K. R. 1998: Isoplot/Ex, version 1.00, a geochronological toolkit for Microsoft Excel. Spec. Publ. 1. Berkeley, CA: Berkeley Geochronology Centre.

Manby, G. M. 1990: The petrology of the Harkerbreen Group, Ny Friesland, Svalbard: protoliths and tectonic signeficance. Geol. Mag. 127, 129-146.

Norrish, K. \& Chappel, B. W. 1977: X-ray fluorescence spectrometry. In J. Zussman (ed.): Physical methods in determinative mineralogy. Pp. 235-237, 257-262. New York: Academic Press.

Parrish, R. R. 1987: An improved micro-capsule for zircon dissolution in U-Pb geochronology. Chem. Geol. (Isot. Geosci. Sect.) 66, 99-102.

Stacey, J. S. \& Kramers, J. D. 1975: Approximation of terrestrial lead isotope evolution by a two-stage model. Earth Planet. Sci. Lett. 26, 207-221.

Streckeisen, A. 1976: To each plutonic rock its proper name. Earth Sci. Rev. 12, 1-33.

Whitehouse, M. J., Cleasson, S., Sunde, T. \& Vestin, J. 1997: Ion microprobe $\mathrm{U}-\mathrm{Pb}$ geochronology and correlation of Archean gneisses from the Lewisian Complex of Gruinard Bay, north-west Scotland. Geochim. Cosmochim. Acta 6, 4429-4438.

Whitehouse, M. J., Kamber, B. S. \& Moorbath, S. 1999: Age significance of U-Pb-Th zircon data from Archean rocks of west Greenland-a reassessment based on combined ion-microprobe and imaging studies. Chem. Geol. 160, 201-224.

Wiedenbeck, M., Allé, P., Corfu, F., Griffin, W. L., Meier, M. Oberli, F., von Quadt, A., Roddick, J. C. \& Spiegel, W. 1995: Three natural zircon standards for U-Th- $\mathrm{Pb}$, Lu-Hf, trace element and REE analysis. Geostand. Newsl. 19, 1-23.

Wilson, M. 1989: Igneous petrogenesis: a global tectonic approach. London: Chapman and Hall. (Copyright now held by Kluwer Academic Publishers.)

Witt-Nilsson, P., Gee, D. G. \& Hellman, F. J. 1998: Tectonostratigraphy of the Caledonian Atomfjella Antiform of northern Ny Friesland, Svalbard. Nor. Geol. Tidskr. 78, $67-80$. 